\title{
Vakıf Araştırmaları Açısından Vakıf Hazine (Atik) Defterleri ve Önemi
}

Mevlüt Çam*

\begin{abstract}
Öz
Vakıflar Genel Müdürlüğü Vakıf Kayıtlar Arşivi vakıfların ana belgesi konumunda olan vakfiyeler başta olmak üzere bünyesinde sair vakıf belgelerini barındıran en önemli arşivlerden birisidir. Arşivde vakfiye defterleri haricinde vakıflarla ilgili muameleler, yapılan iş ve işlemlere ait çok sayıda defter/belge bulunmaktadır. Kısaca bu fonlara değinecek olursak; vakfiye, hazine (atik) defterleri, hurufat defterleri, şahsiyet defterleri, muhasebe, berat, hüccet, hülasa, tescil defterleri gibi ana fonlar ve bu fonlara ait alt bölümlerden oluşmaktadır. Bu fonların en önemlilerinden birisi de hazine (atik) defterlerdir.
\end{abstract}

Hazine Defterleri olarak adlandırılan bu defter serilerinde, vakıf hayrat eserlerde görev yapan kişilerin adları, atanma sebepleri, ölüm veya başka bir sebeple görevden ayrılış nedenleri ve atama prosedürü detaylı olarak verilmektedir. Özellikle büyük vakıflara ait çok sayıda hayrat eserlerde görev yapan hizmetliler, "hayrat" veya "görevler" alt başlıklarında verilmektedir.

İktisadî tarih çalışmaları açısından oldukça önemli veriler içermesine karşılık defterlerin siyakat yazı ile yazılmasından dolayı akademisyenler ve araştırmacılar tarafindan yeterli ilginin gösterilmediğini düşündüğümüz hazîne defterlerinin tanıtıması, metodolojisinin aktarılması büyük önem taşımaktadır. Çalışmamızda Vakıf Kayıtlar Arşivi'nde bulunan Hazîne Defterleri örnekleriyle tanıtılmaya çalışılacaktır.

Anahtar Kelimeler: Hazine (Atik) Defteri, Vakıf, Siyakat.

\section{Waqf Treasury (Old) Registers and Their Significance in Terms of Waqf Studies}

\begin{abstract}
Foundation Records Archive under Directorate General of Foundations, is the most significant archive that includes waqfiya and other waqf records. Besides waqfiyas, there are a lot of registry and documents of transactions, works and issues about waqfs. In brief, these registry documents includes sections of treasury (atik), hurufat, şahsiyet (personage), muhasebe (accounting), berat, hüccet, hülasa, tescil registries and their sub-sections. Treasury (atik) register is one of the most important of these registry documents.

In these register collections, called treasury registers, there is detailed information about the names of staff in these pious deeds, the reasons for and procedures of appointment and dismissal due to death or another reason. Especially, the staff in many pious deeds belonging to the grand waqfs are listed under the sub-titles of "pious deeds" or "duties/works".

Studies on treasury registers and the transfer of its methodology are of great importance. We think, however, that the academicians and researchers are not interested enough due to the fact that the registers are written in siyakat calligraphy although they include quite significant information in terms of economic history. In our study, treasury registers which are available in the Foundation Registry Archive will be introduced.
\end{abstract}

Key Words: Treasury (Old) Registers, Waqf, siyakat (a style of writing used in treasury documents).

* Vakıflar Genel Müdürlüğü, Arşiv ve Tescil Müdürü; m.cam24@gmail.com 


\section{Giriş}

Devletlerin yaptıkları iş ve işlemleri kayıt alttna alması o devletin tarihi süreçteki ana hafizalarını teşkil eder. Osmanlı Devleti'nin hafizasını teşkil eden defter/belge türlerinden en önemlileri olan adlî, askerî ve diplomatik türler haricinde, din, eğitim, sağlık, sosyal ve kültür alanlardaki hizmetleri halka sunan vakıflara ait defterler ve belgelerdir. Vakfiye ve vakıf belgeleri, tarihçiler için olduğu kadar din, tasavvuf, mimarî, sanat tarihi, şehir tarihi, sosyoloji, iktisat, biyografi, kültür, eğitim tarihi ve daha birçok alanda çalışanlar için de birincil kaynaklardır. Bu cümleden olmak üzere Osmanlıda dinî, sosyal, sağlık, eğitim, beledî hizmetler gibi birçok hizmeti yerine getiren vakıflara ait vakfiye, berat, hüccet, hazine, hurufat, ahkam, tafsil, nizamat, yeni şahsiyet defterleri en önemli arşiv vesikalarındandır.

Türkiye'de muhtelif arşivlerde bulunan başta tahrir defterleri, vakıf defterleri, şeriyye sicil defterleri, mühimme ve şikayet defterleri olmak üzere diğer fonlardaki sair defterler Osmanlı döneminde arşivciliğin ve yapılan muamelat kayıt altına almanın ne derece önemli olduğunun da göstergesidir. Askerî, diplomatik, hukukî, vakıfla ilgili ve diğer alanlarda yapılan uygulamaları kayıt altna alma hususunda Osmanlı Devleti'ni en ön saflarda görürüz. Zira fetihle beraber tutulmaya başlanan tahrir kayıtları, devamında mühimme, şikayet defterleri, şer'iyye sicilleri, vakfiyeler, tarihî süreçte düzenlenen maliye kayıtları ve muhtelif muamele defterleri, kanunnameler, hükümler, fermanlar, beratlar, hüccetler, muamelat evrakları ve sair arşiv belgeleri dönemin kültürü, dini, sosyal ve iktisadi hayat, askeri, siyasi ve diplomatik hadiseler ve diğer uygulamalar ile ilgili oldukça önemli bilgiler ve veriler aktarmaktadır. Bu manada Vakıflar Genel Müdürlüğü Vakıf Kayıtlar Arşivi de, bünyesinde bulundurduğu vakfiye, hurufat, hazine (atik), şahsiyet, ahkam, tafsil, tafsil-i nizâmât, mukataa, muhasebe, berat, hüccet, maarif, eytam, hülasa ve sair fonlarda oluşan 8300 üzerinde defter ve 1.000 .000 civarında müstakil evrak ile Türkiye'deki en önemli arşivlerden birisidir. Özellikle vakfiyeler dikkate alındığında ise dünyanın en büyük vakfiye arşivi konumundadır. Bu defterlerden bazı fonların büyük bir kısmı Başbakanlık Osmanlı Arşivleri, çok az bir kısmı ise diğer arşivlerde bulunmaktadır. Ancak bu fonlardan vakıf hazine (atik), hurufat gibi fonlar sadece Vakıf Kayıtlar Arşivi'nde bulunmaktadır.

Çalışmamıza konu olan ve Vakıf Kayıtlar Arşivi'nde bulunan fonların en önemlilerinden olan Hazine (Atik) Defterleri ile ilgili olarak şimdiye kadar yeterli sayıda çalışma yapılmaması nedeniyle literatür oldukça kısıtlı bulunmaktadır. Hatta defterleri kaynak olarak kullanan akademik çalışma sayısı dahi oldukça mahduttur.

Hazine (Atik) Defterler ile ilgili ilk ve en önemli bilgilere Mahmut Yazır tarafindan 1939 yılında hazırlanan Vakıf Kayıtlar Rehberi adlı kitapçıkta rastlıyoruz. Yazır söz konusu defterlerin önemini şu şekilde vurgulamakatadır:

“Hazine Defterleri; vakıfların, Evkaf Nezâretinin teşekkülüne ve hatta ondan epeyi zaman sonraya kadar vakıfların isimlerini ve esas defterleri gibi hademe vezayifini ve bunlardaki tebeddülât vekâyiini hâvî olmak üzere, Sadrazamlık, Şeyhulislamlık, Darussaade Ağalığı, Babussaade Ağalığı, İstanbul Kadılığı ve saire gibi makamların istiğmal ettikleri defterlerdir. Bunların bazılarında yukarda yazılan malumattan fazla olarak vakfin muhasebeleri ve vakfiyeleri gibi kayıtlar da mevcuttur. Bunların muhtelif serileri ol- 
duğu gibi hiç bir seriye tabi olmayanları da mevcuttur. Seriler; Haremeyn, Küçük Evkaf, Mukataa, Anadolu, İstanbul, Rumeli gibi namları intiva eder. Hazine defterlerindeki kayıtlar, kendilerine mahsus fihristler delaletiyle bulunur." (Yazır: 1939: 28).

Günümüze kadar, defterleri çalaışmalarında en geniş kapsamda kullanan kişi rahmetli Ekrem Hakkı Ayverdi'dir. Avrupa'da Osmanlı Mimari Eserleri adlı seri çalışmasında Rumeli vakıfları hazine defterlerine ait olan 757 ve 758 numaralı fihrist defterleri Ayverdi'nin çalışmasının temelini teşkil etmekte olup yüzlerce vakıf esere kaynak olarak gösterilmiştir. Ayverdi kitabının ikinci cildinin medhal (giriş) kısmında bu durumu şu şekilde ifade etmektedir: "Vakıflar Umum Müdürlüğündeki, imam, müezzin, hatip, kayyım gibi hayrat hademesinin tayinlerini gösteren cihât defterleri en geniş, fakat o nisbette muhtasar malumat veren menba'dır." (Ayverdi, 2000; XI).

Mustafa Alkan tarafindan yazılan "Türk Tarih Araştırmaları Açısından Vakıf Kayıtlar Arşivi" adlı çalışmada defterlerden kısaca bahsedilerek, defterlerin siyakat ile yazıldığı ve toplam 610 adet olduğu belirtilmiştir (Alkan, 2007; 8). Ancak çalışmada bu defterler fihrist defterlerinin bir alt bölümü olarak ele alınmış olup, defterlerin içerikleri ile ilgili bir bilgi verilmemiştir. Halbuki defterler vakıf hayrat eserlere yapılan görevli tevcihleri/atamaları ile ilgili belgelerden oluşan kayıtları içermekte olup, defterlerin büyük bir kısmının başında içerdiği belgelerle ilgili fihristler bulunmaktadır veya bir kaç defter grubunun müstakil bir fihristi bulunmaktadır. Dolayısıyla defterlerin fihrist defterleri ana başlığı altında gösterilmesinin hatalı olduğu aşikardır. Alkan yine çalışmasında bu defterdeki kayıtların 1300 H. (1882 M.) tarihinden itibaren Yeni Şah- siyet Defterleri'ne nakl edildiğini belirtse de çok sayıda defterde kayıtlar 1337 H. (1889 M.) tarihine kadar tutulmaya devam edilmiştir. ${ }^{1}$ Ayrıca kayıtların tamamının yeni şahsiyet defterlerine nakledildiği söylemek de eksik bir ifadedir. Aynı hususlara değinilmekle birlikte Alkan'ın araştırmasından farklı olarak, Mevlüt Çam, defter adedini 660 olarak vermektedir (Çam, 2013: 451). Bu fark anılan defterlere Osmanlıca fihristlerin eklenmesi ve bir kaç defterin iç içe bulunduğu tek cilt halindeki defterlerin ayrı ayrı sayılmasından kaynaklanmaktadır.

\section{Vakıf Hazine (Atik) Defterleri}

Evkâf-ı Hümâyun Nezâreti kurulmadan önce vakıfların yönetim işleri vakfiye şartlarına göre yapılmakta, vakıf kurucuları vakıflarının yönetim ve denetim işlerini evlatlarına, kan bağı olan yakınlarına veya devletin herhangi bir makamına şart kılmakta idi. Vakıf kuran padişahların neredeyse tamamına yakını, hanım sultanların büyük bir kısmı, sadrazam, vezir, paşa ve şeyhülislamlar gibi devlet erkanı, vakfin yönetim-denetim iş ve işlemlerini darussaade ağalığı, babussaade ağalığı, şeyhülislamlık, kazaskerlik, kadılık, müftülük gibi makamlara tevdi etmekteydi. Dolayısıyla Evkâf Nezâreti kurulmadan önce vakıfların, yönetim ve denetimle ilgili iş ve işlemleri vakfiyelerindeki şartlara göre, Sadr-ı Âlî Nezâreti, Şeyhülislam Nezâreti, Bâbüssaâde (Kapı) Ağası Nezâreti ve Dârüssaâde Ağası (Haremeyn Evkâfi), Nakibüleşraflık Nezâreti, Hazinedarbaşı Nezâreti, kadılıklar gibi birimler tarafindan yürütülmüştür (Başbakanlık Osmanlı Arşivi Rehberi, 2010: 239). Ayrıca bazı vakıflar da müstakil kadılıklar (Üsküdar, Bursa kadılığı vs.), Hazinedarbaşı Nezâreti, Sekbanağası Nezâreti, Hamidiye Evkâfi Nezâreti, Reisülküttab Nezâreti, Yeniçeri

1 Örnek olarak, VGMA, 2, 36, 39 Numaralı Defterler 
Ağası Nezâreti (Kunter, 1983: 19) vakfiyedeki şartlara göre oluşan çok sayıda nezaret tarafindan teftiş ve denetime tabi tutulmakta idi. Bu on iki nezaretten en önemlisi ve en büyüğü Haremeyn Evkafi Nezâreti idi (Kahraman, 2006: 16). Haremeyn Nezâreti ve diğer nezaretlerce yönetilen veya denetlenen vakıflar ile selatin vakıfları denilen, sultanlar ve diğer hanedan üyeleri tarafindan kurulan vakıflar, esasen devlet reisi veya onun namına memurları tarafindan idare edilmekte iken bir müddet sonra tedricen nezaretlerin yönetim alanına girmiştir. Tevliyeti yani mütevelliliği saltanat makamına ait olan vakıfların idare ve muhafazasında birlik temin edilmesi için Evkâf Nezâreti'ne devredilmişlerdir. Bu vakıflarda Evkâf Nâzırı, mütevelli vekili durumundadır. Evkâf Nezâreti'ne "Evkâf-ı Hümâyûn Nezâreti" denilmesi mütevelliliği sultanlara ait bu vakıflar dolayısıyladır (Öztürk, 1983: 49).

Vakıfların idari işleri, hesapları, tayin ve tevcih gibi iş ve işlemleri de yukarıdaki nezâretlere bağlı bulunan "Haremeyn Muhasebesi", "Anadolu Muhasebesi" ve "Küçük Evkâf Muhasebesi/Kalemi" idareleri tarafindan yürütülürdü. Dolayısıyla Hazine (Atik) Defterleri'nin Bâb-ı Defterî (Maliye Dairesi) birimlerinden olan Haremeyn Muhasebesi Kalemi, Anadolu Muhasebesi Kalemi, Küçük Evkâf Kalemi ve bunların bünyelerinde bulunan alt kalemler (cihât kalemi, tevcihât kalemi vs.) tutulduğunu söyleyebiliriz.

Ayrıca Hazine (Atik) Defterleri tetkik edildiğinde Osmanlı tarafindan Ortadoğu'da fethedilen coğrafyada kurulmuş olan Eyyubi, Memluklu ve Selçuklu vakıfları ile yine aynı coğrafyada ve Anadolu'da kurulmuş olan ve günümüze 100 adet vakfiyesi ulaşan (Çam, 2016: 20-21) Selçuklu ve Beylikler dönemine ait çok sayıda vakfin Haremeyn İdaresi (Dârussaâde Ağaları) tarafindan yönetildiği dikkat çekmektedir.

Toplu olarak Vakıf Kayıtlar Arşivi'nde bulunan ve başka bir arşivde örneği bulunmayan, tamamı siyakat yazı ile kaydedilen "hazine" veya diğer adıyla "atik" defterleri en önemli vakıf defter fonlarından birisidir. Defterler tutuldukları dönemde içeriklerine ve vakıf kurucularının statülerine göre "Selatin Hazine", "Vezir Hazine", "Havatin (Hatunlar) Hazine”, "Kapu Ağası" veya vakıfların kurulduğu ya da akar ve hayratının bulunduğu yerlere göre "Rumeli Hazine Askerî/Muhasebe Defterleri", "Anadolu Askerî/ Muhasebe Hazine Defterleri" şeklinde tasniflenmiştir. Bunun yanı sıra müstakil vakıflara veya aralarında akrabalık bulunan vakıf kurucularına ait "Hanzâde Hazine Defterleri Serisi (Sokullu Mehmed Paşa ve Mülhakât olan vakıflar)", "Aziz Mahmud Hüdai ve Mülhakât Hazine Defterleri", "Merzifonlu Kara Mustafa Paşa Hazine Defteri", "Mihrişah Sultan Hazine Defterleri" gibi farklı isimlerle tutulmuş defterler de arşivde bulunmaktadır.

Hazine (Atik) Defterleri'ne atik denmesinin sebebi kendisinden sonra kayıtların devamının tutulduğu Yeni Şahsiyet Defterleri'nden tarih ve muamelat olarak önceye ait olmasıdır. Defterler tamamen siyakat yazısı ile yazılmış olup, defter aralarında veya defterin baş kısımlarında veya iç kısımlarında "divani" ya da "divani kırması" ile yazılan vakfiye, zeyl vakfiye, berat, hüccet, ferman, ilmühaber, hüküm, tevcih kaydı ve derkenarlara rastlanmaktadır (Çam, 2013: 453).

Defterler vakıf hayrat eserlere ataması yapılan idari ve hizmet görevlilerini ihtiva eder ve genelde ilk sayfalarda defter içeriğinde kayıtlı bulunan vakıflara ait fihristler bulunur (Bkz. 
Ek 1). ${ }^{2}$ Defterler arasında fihrist bulunmayanlara da rastlamak mümkündür (VGMA, Defter No: 21). Bazı defterler aile vakıflarına ait olup, ailenin ilk vakıf kurucusu, kızı/oğlu, kan bağı olan akrabaları veya çalışanlarına ait kişilerin vakıfları bir bütün halinde bu defterlerde bulunmaktadır. ${ }^{3}$

Hazine (Atik) defter serilerinin bir kısmına ait toplu fihristler de bulunmaktadır. Rumeli Askerî olarak adlandırılan ve 399-406 arası Rumeli Hazine defterlerine ait kayıtlar, Arap harfleriyle alfabetik şekilde 757 numaralı defterde fihristlenmiştir (Bkz. VGMA, Defter No: 757). Söz konusu fihrist defterinin Ekrem Hakkı Ayverdi'nin Balkan ülkeleri vakıf eserleri incelemelerinde kullandığı en önemli kaynak olduğu görülmektedir.

758 numaralı defter (VGMA, Defter No: 758); Kırmızı Rumeli (VGMA, Defter No: 725), Beyaz Rumeli (VGMA, Defter No: 723), Cedid Edirne (VGMA, Defter No: 727), Hazine Atik Edirne (VGMA, Defter No: 726), Hazinedarbaşı (VGMA, Defter No: 16), Defter-i Ordu (VGMA, Defter No: 715), Vezir-i Azam (VGMA, Defter No: 5), Saray Ağası (VGMA, Defter No: 11) defterleri Balkan ülkelerine ait vakıflarla ilgili kayıtların fihrist defteridir. Yine 749 (VGMA, Defter No: 749) numaralı defter; Sarı Muhasebe (VGMA, Defter No: 485, 486, 487), Siyah Muhasebe (VGMA, Defter No: 478, 479, 480), Sivas Muhasebe (VGMA, Defter No: 481, 482, 483, 484), Amasya Muhasebe (VGMA, Defter No: 490), Erzurum Muhasebe (VGMA, Defter No: 488, 489) numaralı defterlerin fihristidir.

2 Örnek olarak, VGMA, Defter No: 1, 3, 35.

3 VGMA, Defter No: 2. Bu defter Sokullu (Şehit) Mehmed Paşa, eşi İsmihan Sultan, Sokullu Vakıflarının Katibi Ömer Efendi, Sokullu utekalarından Memi Mehmed Efendi ve Sokullu mülhakatı diğer vakıfların kayıtlarından oluşmaktadır. 75 Numaralı Defter ise Köprülü Mehmed Paşa ve oğlu Fazıl Ahmet Paşa vakıflarına aittir.
Genel olarak defter fonlarının büyük bir kısmının yine siyakatla yazılmış fihristleri bulunmaktadır. Defter ebatları en $14-22 \mathrm{~cm}$, boy $40-55$ $\mathrm{cm}$ aralığında olup sayfa sayıları 8-790 arasında değişmektedir. Defterlerin içerisindeki farklı vakıflara ait olan kayıtlar, genelde birbirlerini takip eden kayıtlar şeklinde (1, 2, 3...105, 106, $107 .$. gibi) numaralandırılmıştır (VGMA, Defter No: 399, 400). Ancak bazı defterlerde mükerrer (aynı numaranın bir kaç defa kayıtlı olduğu) belgelere rastlanmaktadır. Bir kısım defterlerde ise sıra numarası bulunmayıp fihristlerde vakıf kaydının bulunduğu varak sayfası kayıtlı bulunmaktadır (VGMA, Defter No: 1 ve 5).

\section{Hazine (Atik) Defter Fonları/Kısımları}

Haremeyn Fonları: Haremeyn Mukataası, Mihrişah Sultan Haremeyn, Haremeyn Efendiyân Evvel ve Sânî, Haremeyn Şeyhulislam, Haremeyn Paşalar, Haremeyn Sadr-ı Âlî, Haremeyn Atik Rumeli, Haremeyn Rumeli, Anadolu ve Rumeli Mukâtaât, Mekke-Medine Hazine, Hicaz Hazine.

Küçük Evkâf Fonları: Küçük Evkâf Paşalar, Küçük Evkâf Vezir Nezâreti, Küçük Evkâf Şeyhulislam, Küçük Evkâf Havatin, Küçük Evkâf Galata, Küçük Evkâf Üsküdar, Küçük Evkâf Kadı, Küçük Evkâf Kapu Ağası, Küçük Evkâf Saray Ağası, Atik Babussaade Ağası, Şeyhulislam Nezâretindeki Vakıflar Atik Defteri, Küçük Evkâf Hazinedarbaşı, Küçük Evkâf Evvel ve Sânî (Anadolu). Ayrıca bu defterlerin kendi aralarında Anadolu, Rumeli ve Dersaadet adıyla defterleri bulunmaktadır (Küçük Evkâf Vezir Anadolu, Küçük Evkâf Vezir Dersaadet ve Rumeli gibi).

Askerî Fonları: Rumeli Askerî Evvel, Sânî... Sâmin, Anadolu Askerî Evvel, Sânî... Sâmin, Siyah, Sarı, Erzurum Askerî, Sivas Askerî, Bursa Askerî, Diyarbekir Askerî, Üsküdar Askerî, Yeşil Askerî, 
Maraş Askerî, Halep Askerî, Yemen Askerî, Defter-i Ordu-yı Rumeli, Atik Ordu Defteri.

Muhasebe Fonları: Siyah Evvel, Sânî ve Sâlis Muhasebeler, Sivas Muhasebeler 4 adet, Sarı Evvel, Sânî ve Sâlis Muhasebeler, Erzurum Evvel ve Sânî Muhasebeler, Amasya, Bursa, Diyarbekir, Maraş Muhasebeler, Yeşil Muhasebe (Muğla-Mersin Arası), Selâtîn Evvel ve Sânî Muhasebe, Anadolu Mücedded Evvel ve Sânî, Üsküdar Muhasebe, Halep, Şam, Kudüs, Kahire, Trablus, Kudüs Hama-Humus Muhasebeler, Emevi Şam Muhasebe, Umum Evvel ve Sânî.

Müstakil Defterler 1: Bu defterler müstakil bir vakfin, aralarında kan bağı bulunan kişilerin veya bir tekke ya da hayrat eser için vakıf kuran kişilerin vakıflarının hazine kayıtlarının toplandığı defterlerdir. Bazı vakıflara veya vakıf gruplarına ait birden çok defter bulunmaktadır (Ayasofya-i Kebîr, Şehzâde Sultan Mehmed Han, Sultan Süleyman Han, Sultan Osman, Sultan Ahmet Han-ı Evvel, Laleli Sultan Mustafa Han, Koca Mustafa Paşa, Hanzade/Sokullu Mehmed Paşa ve Mülhakât, Kara Mustafa Paşa, Merzifonlu Mustafa Paşa, Köprülü Mehmed Paşa, Hekimzade Ali Paşa, Aziz Mahmud Hüdai ve Mülhakât, Mihrimah Sultan, Beşir Ağa, Mihrişah Sultan, İbrahim Paşa, Bezmialem Valide Sultan vs.).

Müstakil Defterler 2: Bu defterler coğrafi bir bölgede kurulan vakıflara ait hazine (atik) kayıtlarının yazılı olduğu defterlerdir. (Rumeli Beyaz (VGMA, Defter No: 723), Rumeli Kırmızı (VGMA, Defter No: 725), Edirne Atik Hazine (VGMA, Defter No: 721, 726), Edirne Selâtîn Atik (VGMA, Defter No: 720), Rumeli Girit (VGMA, Defter No: 724), Ordu-yı Hümâyûn, Atik Ordu Defterleri (VGMA, Defter No: 715, 716, 717, 718).

Defterler içerisinde ayrıca bazı vakıflara ait ta'âmiye, lahmiyân, duaguyân gibi mürtezikalardan bir topluluğun kayıtlı olduğu defterler bulunmak- tadır (Ayasofya-i Kebîr Duaguy Defteri, Ayasofya, Şehzâde, Eyüp, Atik Valide Sultan Süleyman, Sultan Orhan, II. Murat Ta'âmiye ve Lahmiye Defteri, Ayasofya-i Kebîr Ta'âmiye ... gibi).

\section{Hazine (Atik) Defterlerinin Kayıt Metodolojisi:}

Hazine (Atik) Defterleri, cami, mescid, tekke, türbe, çeşme, suyolu, han, ${ }^{4}$ misafirhane, imaret, medrese, mekteb, daruşşifa gibi vakıf hayrat eserlerde görev yapan imam, hatip, tabip, ferraş, müderris, muallim, suyolcu gibi veya vakıftan bir şekilde faydalanan eczahân, duaguyân, taâmiyehân gibi mürtezikaların kayıtlı olduğu defterler olup, kaydın hemen başında ilgili vakfin tam adı, devamı olan kısımda ise görevli kayıtları yer alır. Vakıf hayrat eserlerde görev yapan veya faydalananlar vakfin büyüklüğüne ve görevli sayısının çokluğuna göre hayrat eser adı ve görevlileri (ya da görevli grupları) alt başlıkları halinde yazılmştır. İlk görevli kayıtlarının başlangıcı üçgen halinde olan kısımdır; burada defterde kayıtlı ilk görevlinin adı, görev türü ve günlük veya aylık olarak aldığı ücret yazılıdır. Üçgen halinde kayıtlı bulunan ilk görevliden sonra yapılan atamalar zincirleme olarak devam etmekte ve çizgilerle takip edilmektedir. İlk atamadan sonra gelen görevlinin kendisinden önceki görevlinin ölümü, azli, ferağı, el çektirilmesi, becayiş gibi hangi sebeplerden dolayı göreve geldiği, göreve gelmesine dair resmi prosedürün ne şekilde olduğu ve atanma tarihi yer alır. Örnek olarak Mahmud Paşayı Veli Vakfi'na ait hazine (atik) kaydının ana ve alt kayıtlarının transkripsiyonu verilmiştir (VGMA, Defter No: 106, sıra 10; Belge 1). ${ }^{5}$

4 Han; Genel olarak vakfiyelerde misafirlerin ücretsiz konaklayacakları bir yapı olarak zikredilmekle beraber, bazı vakfiyelerde de vakfa gelir getiren akarlardan olarak değerlendirildiği görülmektedir. Burada "han"ı hayrat olarak kullanmayı daha uygun bulduk.

5 Ana kayıt altında bulunan alt kayıtlarda geçen hizmet grubu cemaatler farklı sayfalarda kayıtlı olup, örnek olarak yalnızca bir sayfa görüntüsü verilmiştir. 


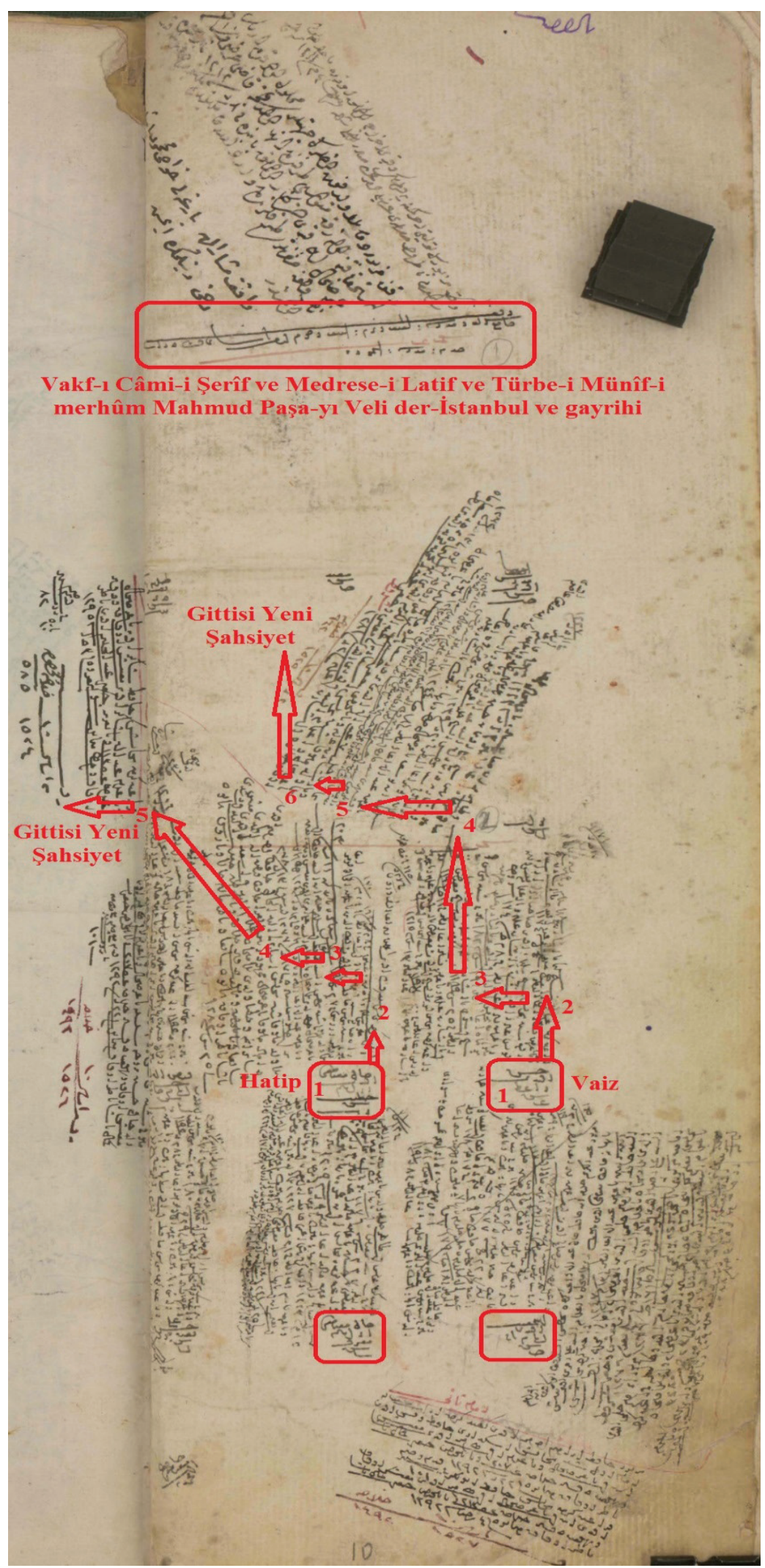

Belge 1. VGMA, Defter No: 106, s. 10.

Vakıflar Dergisi 47 - Haziran 2017

$$
\text { ब2 } 51
$$




\section{Belge 1. Transkripsiyon:}

Vakf-ı Câmi-i Şerîf ve Medrese-i Latif ve Türbe-i Münîf-i merhûm Mahmud Paşa-yı Veli der-istanbul ve gayrihi (Ana kayit).

Cemâ'at-ı Hademe-i medrese-i Memhûre.

Cemâ'at-ı Câmi'-i Şerif.

- Cemâ'at-i Devirhân-ı Câmi'-i Şerîf.

- Cemâ'at-i Eczâhanân-ı Câmi'-i Şerîf.

- Cemâ'at-i Müezzinân-ı Câmi'-i Şerîf.

- Cemâ'at-i Kayyûmân, Sirâciyîn, Ferraşân ve Bevvâbân-ı Câmi'-i Şerîf.

Cemâ'at-i Türbedârân.

Cemâ'at-i Muallimân.

Cemâ'at-i Ta'âmhorân ve Duâguyân.

Cemâ'at-i Hademe-i Imâret.

Cemâ'at-i Zâbıtân-ı Vakf ve Kâtibân ve Câbiyân ve Mu'temedân ve gayrihi.

Cemâ'at-i Mescid ve Hân der-Burusa.

Cemâ'at-i Hademe-i Mescid-i merhûm Şeref Ağa.

Cemâ'at-i Hademe-i Mescid-i müşârun ileyh der-Mahalle-i Servi.

Cemâ'at-i Hademe-i Câmi'-i merhûm Mahmud Paşa-yı Veli der-Edirne.

- Cemâ'at-i Müezzinân-ı Câmi'-i mezbûr.

- Cemâ'at-i Kayyımân ve Sirâciyân-ı Câmi'-i mezbûr

Cemâ'at-i Hademe-i Câmi'-i Şerîf der-Sofya.

Cemâ'at-i Hademe-i Câmi've Medrese der-Hasköy tâbi'-i kazâ-i Edirne.

Cemâ'at-i Kâtibân ve Câbiyân-ı Kurahâ-i vâkıf-ı müşârun ileyh der-Çatalca.

Cemâ'at-i Hademe-i Mescid-i Şerîf der-Karye-i Mehluz.

Cemâ'at-i Hademe-i Câmi'-i Şerîf-i Hacı Bayram Sultan der-Ankara an-mülhakât-ı vakf-ı mezbûr.

Cemâ'at-ı Zâbitân-ı Hademe-i Câmi'-i Şerîf-i Ankara an-mülhakât-ı vakf.

Cemâ'at-i Hademe-i Câmi'-i Şerîf-i iki Şerefeli der-Ankara. ${ }^{6}$

6 VGM Defter: 106, s. 10-49.
Vakfin hayratlarında 18 görevli grubunun hizmet ifa ettiği anlaşılmaktadır.

Bu görev gruplarından örnek olarak vâkıfin hayrati olan Istanbul'da Mahmut Paşa Camii'nde görev yapan hizmet grubundan vâizleri ele alabiliriz:

- Hasan Efendi Vâiz yevm 10 akçe (ilk atama),

- Ferâgat-kerde becâyeş Şeyh Süleyman bâ- işâret-i Şeyhulislam ve bâ-arz-ı Beşir Ağa en-Nâzır fi 10 Zilka'de sene 1171,

- Müteveffâ-şode becâyeş Vâiz Abdurrahman Efendi bâ-işâret-i Şeyhulislam ve bâ-arz-ı Beşir Ağa en-Nâzır fi Selh-i Şevvâl sene 1174,

- Ref'-şode becâyeş Şeyh Süleyman Efendi sâhib-i evveli edâ' fevti gayri vâki' şode bâ-işâret-i aliyye ve bâ-ilâm-ı müfettiş-i Haremeyn ve bâ-arz-ı Beşir Ağa en-Nâzır fi 28 Zilhicce sene 1174,

- Müteveffâ-şode becâyeş Evliyâ Ahmed Efendi bâ-işâret-i aliyye ve bâ-arz-ı Burhan Ağa en-Nâzır fỉ 19 Şa'bân sene 1182,

Müteveffâ-şode becâyeş Şeyh Mehmed Sırrı bâ-işâret-i aliyye ve bâ-arz-ı Beşir Ağa en-Nâzır fi 25 Şa'bân sene 1189,

- Ferâgat-kerde becâyeş Şeyh Mustafa Mehmed bâ-işâret-i aliyye ve bâ-arz-ı Beşir Ağa en-Nâzır fí 11 Cemâziye'l-âhir sene 1192,

Ferâgat-kerde becâyeş Konevî eş-Şeyh Mehmed Efendi bin Mustafa bâ-işâret-i aliyye ve bâ-arz-ı Idris Ağa en-Nâzır fí 20 Ramazan sene 1197,

- Müteveffâ-şode becâyeş Mehmed Tahir Efendi bâ-işâret-i aliyye ve bâ-arz-ı Idris Ağa en-Nâzir fi 25 Şa'bân sene 1215,

- Müteveffâ-şode becâyeş Şeyh Ali Efendi Hüseyin bâ-arzuhâl-hod ve bâ-işâret-i Dürrizâde es-Seyyid Abdullah Efendi ve bâ-arz-ı Kasım Ağa en-Nâzır fi 11 Zilka'de sene 1227,

- Bilâ-veled müteveffâ-şode becâyeş eş-Şeyh Halil bâ-arzuhâl-hod ve bâ-işâret-i Mekkizâde Mustafa Asım Efendi Ağa bin Ebubekir Ağa en-Nâzır fi 20 Zilhicce sene 1239, 
- Müteveffâ-şode becâyeş Karaağacî Süleyman ibn Yusuf bâ-arzuhâl-hod ve bâ-inhâ-i mütevellî ve bâ-işâret-i aliyye ve bâ-arz-ı Abdullah Ağa en-Nâzır fí 18 Cemâziye'l-âhir sene 1244,

- Bilâ-veled müteveffâ-şode becâyeş Akşehîrî Seyyid Hâfiz Mehmed Emin bin Veliyyüddin Halîfe an-talebe-i ulûm bâ-arzuhâl ve işâret-i aliyye ve bâ-telhîs-i Seyyid Mehmed Hasib Paşa Nâzır-ı Evkâf-ı Hümâyûn fi 14 Rebî'u'l-evvel sene 1261,

- Ferâgat ve keffi-yed kerde becâyeş Hâfiz Hüseyin bin Mustafa Halife bâ-arzuhâl ve lede'l-imtihân ve bâ-i'lâm-ı Seyyid Mehmed Sadeddin Efendi Müfettiş ve işâret-i aliyye ve bâ-telhîs-i Mehmed Hasib Paşa Nâzır-ı Evkâf-ı Hümâyûn fi 20 Receb sene 1263,

- Müteveffâ-şode becâyeş Halil bin Abdullah Efendi an-Dersiâmân-ı Câmi'-i Süleymâniye bâ-arzuhâl ve bâ-işâret-i aliyye ve bâbâ-telhîs-i hazret-i Hasib Paşa Nâzır-ı Evkâf-ı Hümâyûn fí 13 Zilka'de sene 1272,

- Bilâ-veled müteveffâ -şode becâyeş Ispartalı Abdulkerim Efendi ibn Süleyman an-Dersiâmân-ı bâ-arzuhâl ve i'lâm-ı es-Seyyid Mehmed Kadri Efendi müfettiş ve ve hazret-i Abdulhamid Ferid Efendi Nâzır-ı Evkâf-ı Hümâyûn ve işâret-i aliyye fi 2 Rebî'u'l-âhir sene 1281.

Görüldüğü üzere Hazine (Atik) Defterindeki herhangi bir görevlinin ilk kaydı belirlendikten sonra devamında gelen ikinci görevli ve daha sonraki görevlilerin takibi yapılırken kaydın hemen başında yeni görevlinin geliş sebebi belirtilir. Bu sebepler genelde "müteveffa", "azl, "ferağ", "keffi yed/kasr-ı yed" ya da "ref'" yani ölüm, azil, feragat etme, görevden uzaklaşttrma veya görevden el çektirme şeklinde ifade edilir. Kişinin göreve atanma sebebi yazıldıktan sonra gelen yeni görevlinin varsa lakabı, adı ve baba adı, görevlinin atanma işleminin nasıl gerçekleştirildiği (bürokratik detaylarıyla) ve son olarak da atanma tarihi kaydedilir.

Belge 1'de görüldüğü üzere vakfin ana başlığından sonra vakfin hayratları ve bu hayratlarda görev yapan kişiler, görev türleri, göreve atanma sebebi, görevden ayrılma nedeni, atanma tarihi ve atanma prosedürü detaylı bir şekilde yazılmaktadır. illk bakışta karışık gibi görünen defterlerdeki üçgene benzer öbek kayıtlar, atama yapılan görev türü ile ilgili ilk kayıtlardır. Bunların atanma tarihi bulunmaz, ancak devamında gelen kayıtlarda yerine atanan kişinin atanma prosedürü, atanma sebebi ve tarihi yer alır. Görevlilerinin tespitini yaparken çizgilerin takip edilmesi veya kaydın hemen üst veya yan tarafinda kayıtları birbiri ardında takip etmek çok önemlidir. Dikkatli takip edildiğinde görevlilerin birbiri ile karıştrılma intimali yoktur. Böyle bir takibi yapmak ise tecrübeyi gerektiren bir husustur.

Ayrıca her alt başlığın devamında bulunan çaIışanlara ait kayıtlardan vakfin hayrat eserlerinde kaç kişinin çalıştiğı ve toplamda ne kadar insana istihdam imkanı sağlandığı ve bu kimselerin toplumsal statüleri ve mesleklerini tesbit etmek mümkündür.

Diğer bir husus da yine Belge 1'de görülen ve incelemeye konu "Mahmud Paşa-yı Veli Vakf"na ait hazine (atik) kaydı, vakfiyesi günümüze ulaşmayan vakfin kendi bina ve inşası olan hayrat eserlerin nerelerde olduğu, hangi vakıf eserlere destek verildiği konularını ortaya çıkarma imkanı sağlamaktadır. 


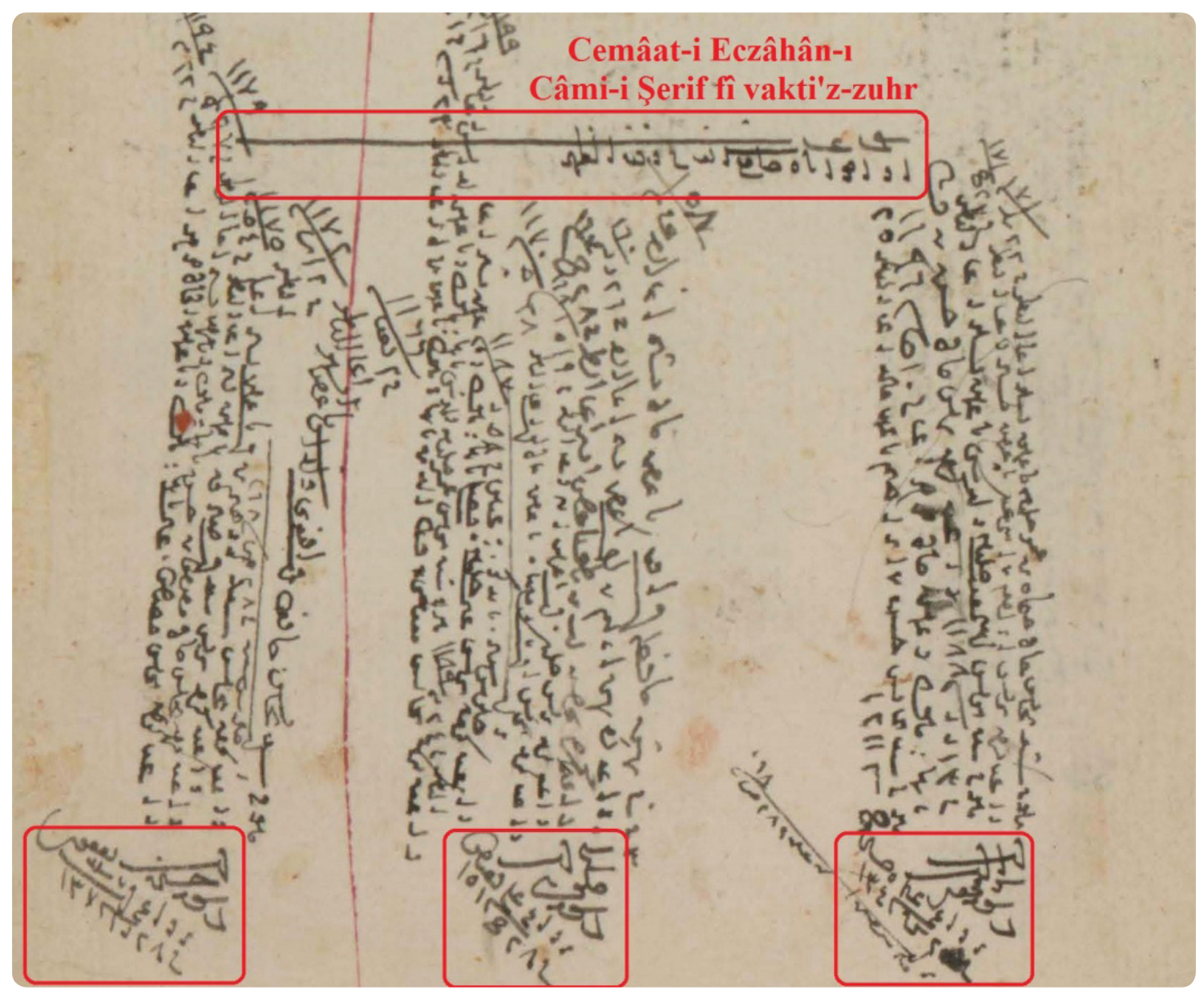

Belge 2. VGMA, Defter No: 106, s. 53.

Görevli sayısı veya genel olarak mürtezika sayısı fazla olan vakıfların görevli grupları bir bütün halinde alt başlıklar halinde verilmektedir. Bu başlıklar genel olarak görevlilerin görev türleri veya görev yaptı̆ı esere göre tasniflenmekte- dir. "Eczahanân-ı Câmi'-i Şerîf-i fî-Vakti'z-Zuhr", "Eczâhânân-ı Vakti'l-işâ", "Cemâat-i-Fethhavân-ı (Fetihhân) Câmi'-i Şerîf fî-Vakti'z-Zuhr", "Cemâat-i Dersiâmân", "Cemâ‘at-i Müezzinân, Ferrâşân" gibi (Bkz. Belge 2). 


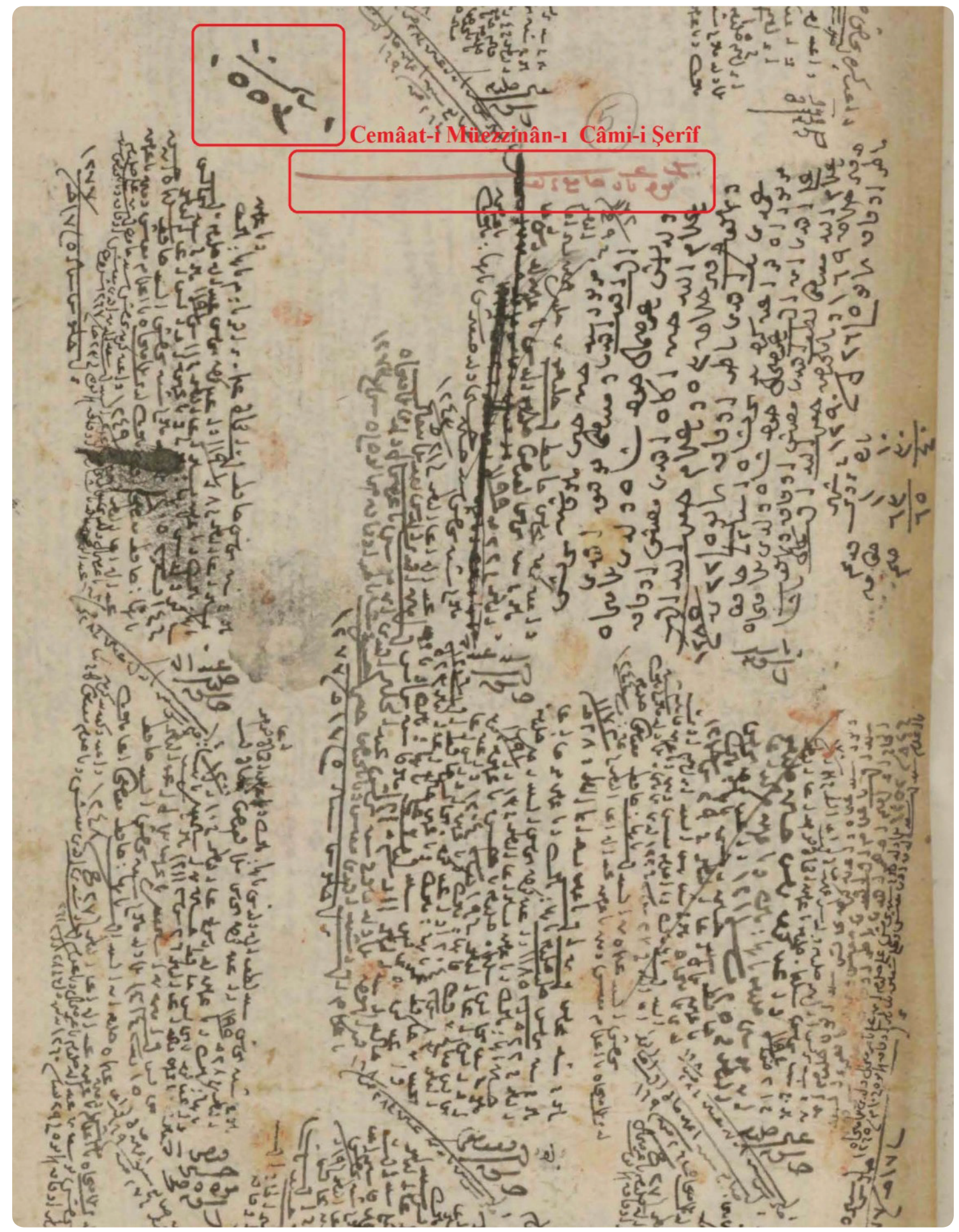

Belge 3. VGMA, Defter No: 106, s. 17.

Yine yukarıdaki kayıtta görüldüğü üzere İstan- zin, iki adet sala müezzini, bir adet akşam mübul'da "Mahmud Paşa-yı Veli Camii'nde" bir ezzini olmak üzere toplam sekiz adet müezzin kişi müezzinbaşı olmak üzere dört adet müez- görev yapmaktadır (Bkz. Belge 3). 


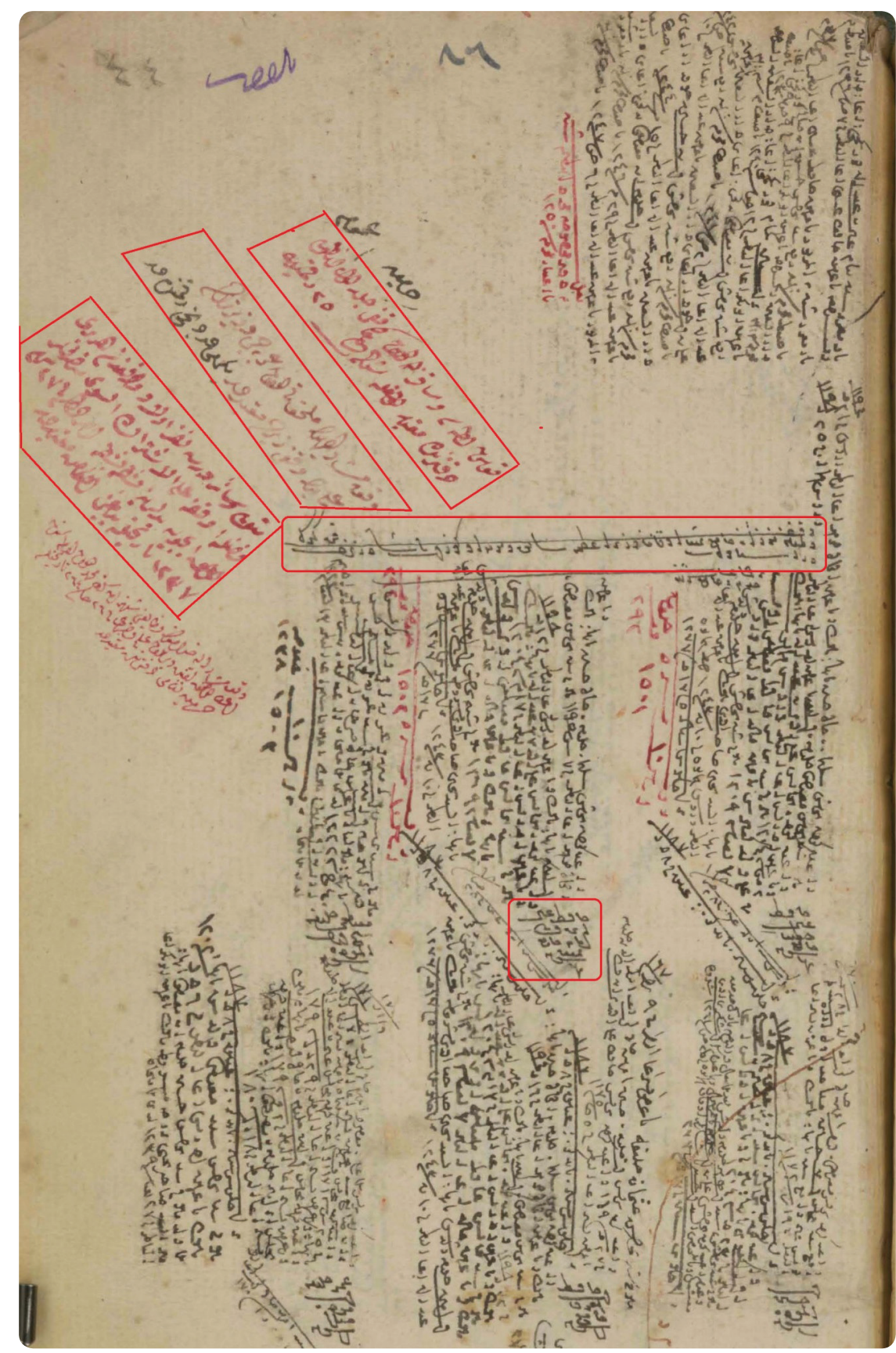

Belge 4. VGMA, Defter No: 106, s. 95.

Bazı hallerde kaydın gittiği defterler "reft" veya "nakil" çizgilerinin sonuna açık bir şekilde yazılır. Son görevlinin yazılmasından sonra kayıt yeni şahsiyet defterlerine aktarılırsa bu durumda gittiği şahsiyet defterinin numarası yazılır ve kaydın intikal ettiği kayıt numarası da açık bir şekilde belirtilir. Yine vakıfla ilgili diğer fonlarda (tafsil, ahkam, nizamat vs.) önemli bir bilgi varsa veya başka bir defterde aynı vakfin hazine kaydı var ise ana kaydın üst tarafina veya yan taraflarına renkli yazı (genelde kırmızı veya mavi) ile şerh düşülerek diğer defterlere yönlendirmeler ve bilgilendirme yazılır. 


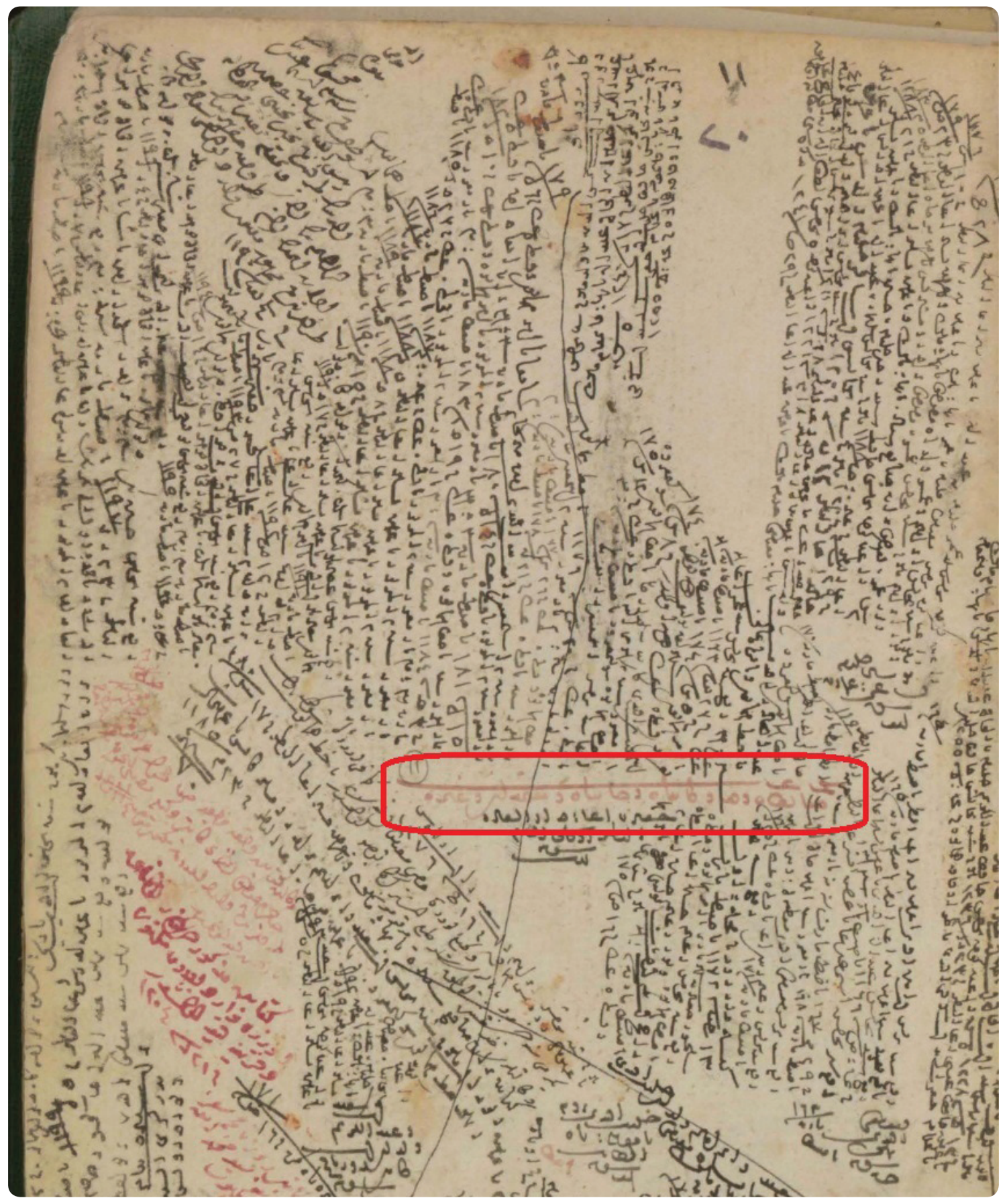

Belge 5. VGMA, Defter No: 106, s. 29.

Görevliler arasında bulunan ve "Cemâ‘at-ı görevlileri (imam, hatip, müezzin, ferraş, kayZâbıtân" başlığı altında kayıtlı bulunan görevliler, vakfin idarî görevlileri olan mütevellî, câbî, kâtib ve nâzırdan oluşan görevlileridir. Diğer yım, sergici, muvakkit, noktacı, müderris, halife, suyolcu, meremmetçi, kilerci, anbarcı, şeyh vs.) ile vakıftan faydalanan duaguy, yasinhân, görevliler veya mürtezikalar ise vakıf hayrat tebarekehân, eczahân gibi vakfiyede tayin edieserlerde bilfiil görev yapan ana hizmet birimi len şartlar dahilinde gün veya zaman aralığın 
da camide toplanan ${ }^{7}$ veya gibi bilfiil çalışmayan ancak kendisine bir nevi ev ödevi gibi tevdi edilen ${ }^{8}$ şartları yerine getiren kimselerdir.

Yine Hazine (Atik) defterler incelendiğinde özellikle duaguy ve eczahânların vâkıfin evlatlarından (VGMA, Defter No: 730, s. 62.), azatlı köle ya da hizmetlilerinden (VGMA, Defter No: 574 , s. 148) veya vakfin eserinin bulunduğu civardaki mahallelerin fukaralarından seçildiği, vefat eden mürtezikanın yerine fakir ise oğlu/ kızının o göreve atandığı eğer fakir değiller ise ahaliden fakir kimselerin seçildiği görülmektedir. Aynı şekilde ta'âmiye ve lahmiye defterlerinde vakıf imaret, aşhane gibi kuruluşlardan yemek yiyen fakirler, vefat edenin yerine yemek tahsisi yapılan kimseler ve kendilerine kuru gıda (ekmek, pirinç, un vs.) tahsis edilen kimseler kayıtı bulunmaktadır.

Defterlerin en önemli özelliklerinden biri de tarihî süreçte vakfin işleyişi ve görevlilerin atanması hakkında önemli bilgiler aktarmasıdır. Ayrıca kayıtlarda bir vakfa ait vakfiyede yer almayan bir hüküm uygulanırsa, bu durum, kaydın alt başlıklarında renkli kalemle (kırmızı, bordo veya mavi) "haric-i ez-vakfiyye" olarak belirtilmektedir. Bu cümleden olarak Fatih Sultan Mehmed tarafindan kurulan ve Ayasofya Vakfi olarak da isimlendirilen 875/1463 tarihli vakfiyede zikredilmeyen ve tarihî süreçte geliri kalmayan veya yeterli olmayan 30 civarında cami, mescid ve medrese gibi hayrat eserlerin Darussaade Ağası yönetim ve denetimi altında bulunan Fatih Sultan Mehmed'in Ayasofya ve diğer eserleri için kurduğu vakıflar tarafindan desteklendiğini bu vakfa ait kayıtların yeraldığı Hazine (Atik) defterlerden öğrenmekteyiz (VGMA, Defter No: 73, s. 73-80).

7 Baruthâne Nazırı Ahmed Bey bin Mehmed Bey 1735 vakfiyesinde iki adet eczâhanın Üsküdar'da yaptırdığı camide her gün bulunarak birer cüz okumasını hüküm altına almıştır.

8 Ayşe Hatun binti Abdullah 1781 tarihli vakfiyesinde alt adet hizmetçisi ve azatlı kölerini duaguy olarak görevlendirerek kendilerine vâkıfenin ruhuna dua etmeleri karşılığında günlük dörder akçe ücret verilmesini hüküm altına almıştır.

\section{Hazine (Atik) Defterlerin Önemi:}

Hazine ya da "atik" adıyla anılan defterler henüz yeterince incelemeye, araştırmaya konu olmamış defter fonlarındandır. Bu defterlerin çalışılması ile sosyal, kültürel hayatımıza ve geçmişimize nasıl katkıda bulunulabileceği, aşağıdaki hususların aydınlatılması açısından mühimdir:

- Hazine (Atik) defterlerinde tarihî süreçte hayrat görevlileri açısından vakıfların işleyişi (görevli atamalarında vakfiye şartlarını uyulup uyulmadığı),

- Vakfiyesi günümüze intikal etmemiş vakıf kurucularının hayrat eserlerinin neler olduğu veya hangi vakıf eserlerin desteklendiği,

- Zaman içerisinde geliri kalmayan vakıfların hayrat eserlerin nasıl yaşatıldığı,

- Vakıf eserlerde istihdam edilen kimselerin görevlerinden alınma sebepleri, ücretleri, istihdam daralması veya genişlemesi ve görev zamlarının ne şekilde yapıldığı,

- Önemli devlet adamları, meşayih, şairler edibler, tarihçiler, nakkaşlar, hattatlar, müfessirler, hukukçular, ilmiye mensuplarının nerelerde görev yaptı̆̆ ${ }^{9}$,

- Tarihi süreçte vakıf akar veya hayratlar üzerinde fiziki değişimlerin ne şekilde vuku bulduğu, ${ }^{10}$

9 Konu ile ilgili olarak, Fatih Sultan Mehmed, Kanuni Sultan Süleyman ve diğer büyük vakıflara ait özellikle camilerde görev yapan imam, hatip, medreselerde görev yapan müderris ve türbelerde görev yapan türbedarlar içerisinde önemli isimlere rastlanılmaktadır. Son devrin Halveti Şeyhlerinde birisi olan Ahmed Amiş Efendi'nin Fatih Türbedarı olduğunu bu defterler ve devamı olan yeni şahsiyet kaydı defterlerinden öğrenmekteyiz.

10 Cezayirli Gazi Hasan Paşa Vakfina ait Gelibolu'da beş dönümlük arazinin Çanakkale deniz muharebelerinde şehit olan denizcilere kabristan olarak mukataaya bağlanarak tahsis edildiğini, Beyoğlu'nda Kuloğlu Mahallesinde bir hanenin yıllık yüz altmış kuruş mukataa bedeli karşılığı Beyoğlu Fransız Mektebine ilhak edildiğini, Kasımpaşa Kışlası içerisindeki cami imam ve görevlilerine meşruta beş adet hanenin yandığını ve bu beş hanenin Bahriye Nezaretince (vakfin mütevellisi olması sebebiyle) yeniden inşa edildiğini vakfa ait atik defterlerinde tafsil ve ilmühaber defterlerine göndermeler yapan derkenarlardan tespit ediyoruz. 
- Vilayet, kaza, nahiye merkezlerinin nâm-ı diğerlerinin neler olduğu ve ne gibi isimlerle anıldığı,

- Yine tarihi süreçte geliri kalmayan ve başta Haremeyn Evkaf İdaresi ve Darussaade, Babussaade, Şeyhulislam, Hazinedarbaşı vs. yönetiminde veya nezaretlerinde bulunan vakıflarca desteklenen ve bakım-onarım dahil her türlü giderleri karşılanan küçük çaplı hayrat yapıların hangileri olduğu...

Bu ve benzeri konularda sosyal, kültürel, iktisadi araştırmalara katkıda bulunacak oldukça önemli bilgi ve belgeye ulaşabiliriz. Zaman içerisinde görevli ücretlerine yapılan zamları da bazen içerisine alan bu kayıtlardan, vakfiyesi mevcut olan vakıfların vakfiyelerinde öngörülen görevlileri ve ücretleri ile tarihi süreçteki görevli ücretleri ve sayıları çıkartılarak, istihdam daralması/genişlemesi, ücret zammı ve sair iktisadi konularda önemli veriler çıkarılabilir.

Ayrıca defterlerde vakıf eserlerin şöhretli isimleri nâm-ı diğerleri, kaza, kasaba, köy, mahalle isimleri gibi konularda kayda değer bilgilere ulaşabiliriz. Dolayısıyla söz konusu defterlerin incelenmesinin vakıf medeniyetimizle ilgili pek çok uygulamanın açığa çıkmasına da katkıda bulunacağı muhakkaktır.

\section{Sonuç}

Hazine ya da diğer adıyla "atik" defterlerin, vakfiyelerden sonra vakıflarla ilgili araştırmalar yapacak kişiler için en önemli kaynak olduğunu söylesek mübalağa etmiş olmayız. Zira hazine (atik) defterleri bize onlarca kaydı araştırıp inceleyerek ancak ulaşabileceğimiz veya ulaşamayacağımız verileri toplu halde sunmaktadır. Gerek bu yönüyle gerekse vakıf hayrat eserlere kuruluşundan itibaren silsile halinde ulaşmamızı sağlayan bu defterleri görmezden gelmek imkansızdır.

Siyakat yazı ile yazılması nedeniyle günümüz araştırmacılarınca uzak durulan hazine (atik) defterlerinin ve buna benzer diğer arşivlerde bulunan kayıtların incelenmesi büyük önem arzetmektedir. Tuttuğu kayıtlarla ve yaptğı işlerle, eserlerle dünyaya örnek olan bir medeniyetin devamı olarak geçmişin uygulamalarından örnekler alarak ancak yeni bir medeniyet tasavvur edebiliriz. Sosyal bilimler alanında eğitim veren üniversitelerimize baktı̆ımızda maalesef divani, divani kırması, siyakat gibi yazı türlerinin yeterli öğretilmediğini, hatta hiç öğretilmediğini görmekteyiz. Halbuki Osmanlı'nın en önemli belgelerinden olan Tahrir Defterleri, Maliye Defterleri/Belgeleri, Vakıf Defterleri/Belgeleri, İnşaiyye ve Muhasebe Defterleri büyük oranda zikredilen yazı türü ile yazılmıştır.

Burada bir örnek vermek gerekirse Ayasofya Vakfi'nın (875 h. tarihli vakfiye ile kurulan) bütün hizmetlerini, görevlilerini, imaretlerinden faydalananları, hayratlarında görev yapanları silsile halinde dizerek günümüze kadar getirmek mümkündür.

Bir devletin yaptığı bütün iş ve işlemlerin kayıt altına alınması, gelecek nesillere önemli bir tecrübe aktarımı sağladığı gibi, yeni nesillerin de yapacakları iş ve işlemlere dayanak olması ve geçmişte yapılan uygulamaların gelecek nesillere temel teşkil etmesi açısından oldukça önemlidir. Bütün bu işlerin yapılabilmesi için kalifiye insan yetiştirilmesi ve eğitilmesi büyük önem arz etmektedir. Biz bu çalışmamızda kısaca bu defterlerin öneminden bahsederek konu ile ilgili bir kapı aralamaya çalıştık. Temennimiz, kültür kaynaklarımızın en önemlilerinden olan arşiv kaynaklarının sosyal bilimler, dini ilimler ve iktisadi ilimler alanlarında çalışmalar yapan akademisyenler ve araştırmacılar tarafindan yeterince incelenmesi, irdelenmesi, elde edilen verilerin gelecek kuşaklara doğru bir şekilde aktarılmasıdır. 


\section{Kaynaklar}

\section{1-Arşiv Kaynakları}

Vakıflar Genel Müüdrlüğü Arşivi (VGMA), Defter No: 1, 2, 3, 5, 21, 35, 36, 39, 73, 75, 105, 399, 400, 574, 749, 757, 758, 761.

\section{2- Araştırma ve Inceleme Eserler}

Alkan, Mustafa (2007). "Türk Tarihi Araşttrmaları Açısından Vakıf Kayıtlar Arşivi". Vakıflar Dergisi, XXX: s. 1-34.

Ayverdi, E. Hakkı (2000). Avrupa'da Osmanlı Mimari Eserleri, Romanya Macaristan. İstanbul Fetih Cemiyeti Yay. İstanbul.

Ayverdi, E. Hakkı (2000). Avrupa'da Osmanlı Mimari Eserleri, Yugoslavya. İstanbul Fetih Cemiyeti Yay. İstanbul.

Başbakanlık Osmanlı Arşivi Rehberi (2010). Başbakanlık Basımevi, İstanbul.

Çam, Mevlüt (2013). "Vakıf Medeniyeti ve Vakıf Kayıtlar Arşivi". Osmanlı Coğrafyası Kültürel Arşiv Mirasının Yönetimi ve Tapu Arşivlerinin
Rolü Uluslarası Kongresi Bildiriler Kitabı. Ankara, Korza Yayıncılık. s. 447-464.

Çam, Mevlüt (2016). 16. Yüzyıl Osmanlı Dönemi Arapça Vakfiyeler Ve Osmanlı Sisteminde Eğitim (Saraybosna Hüsrev Bey ve Edirne Sultan Selim Medreseleri Örneğinde). Gazi Üniversitesi, Eğitim Bilimleri Enstitüsü Yayınlanmamış Yüksek Lisans Tezi, Ankara.

Kahraman, S. Ali (2016). Evkâf-ı Hûmayûn Nezâreti, Kitabevi Yay. İstanbul.

Kunter, H. Baki (1983). Vakıf Kayıtlar Arşivi'ndeki Tarihi Vesikalar. Vakıflar Genel Müdürlüğü Yay. Ankara.

Öztürk, Nazif (1983). Menşei Ve Tarihi Gelişimi Açısından Vakıflar. Vakıflar Genel Müdürlüğü Yay. Ankara.

Yazır, Mahmut (1983). Eski Yazıları Okuma Anahtarı, Vakıflar Genel Müdürlüğü Yay. Ankara. Yazır, Mahmut (1939). Vakıf Kayıtlar Rehberi. Vakıflar Genel Müdürlüğü Yay. Ankara. 


\section{Ekler}

Ek 1: Rumeli Fihristi'nden bir bölüm (VGMA, Defter No: 757)

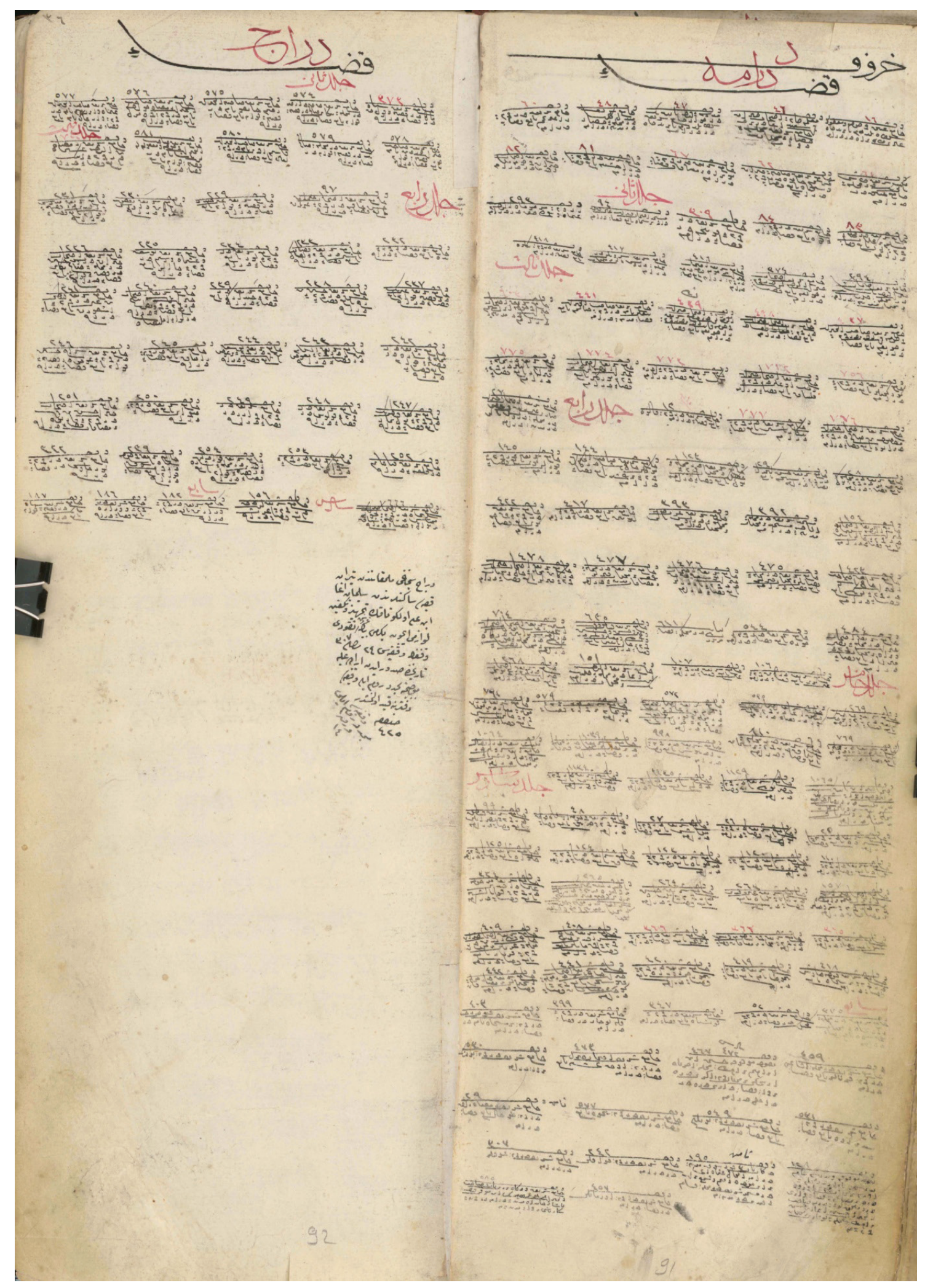


Ek 2: Küçük Evkâf Paşalar defterinden bir sayfa (VGMA, Defter No: 1)

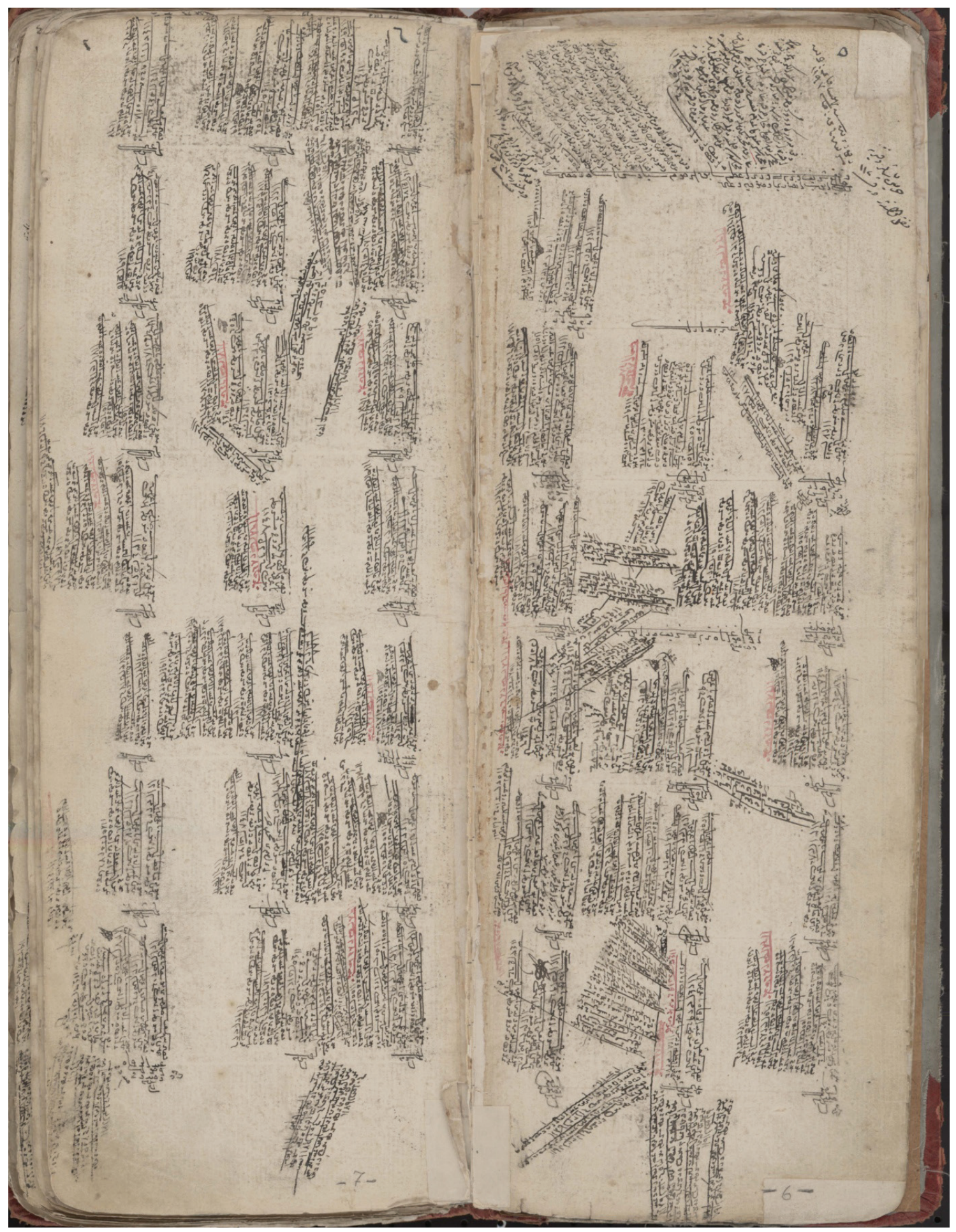


Ek 3: Numaralı Haremeyn Sadr-ı Âlî defterinin ilk sayfası (VGMA, Defter No: 107)

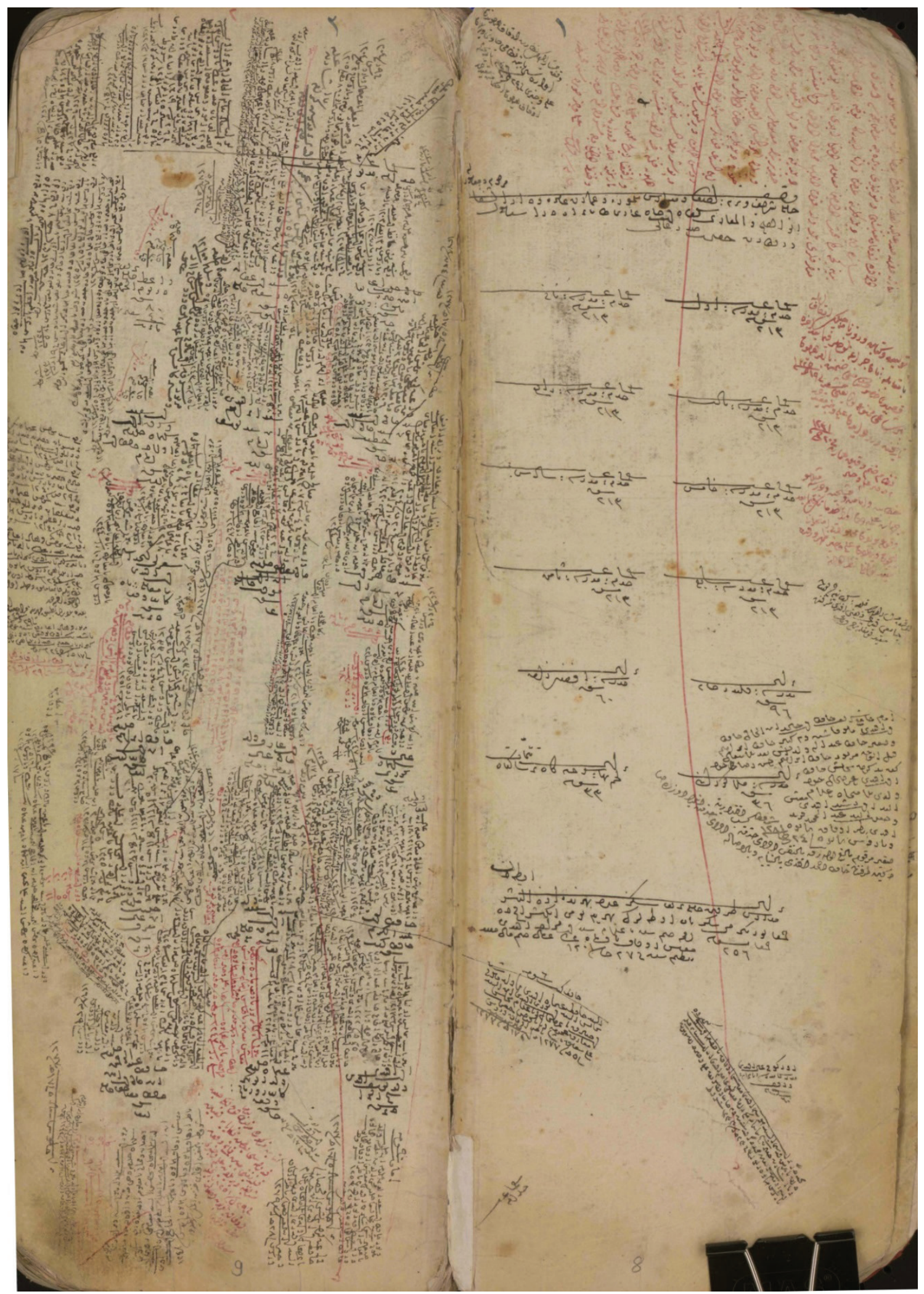

Vakıflar Dergisi 47 - Haziran 2017 
Ek 4: Haremeyn Sadr-ı Âlî defterinin ikinci sayfası (VGMA, Defter No: 107)

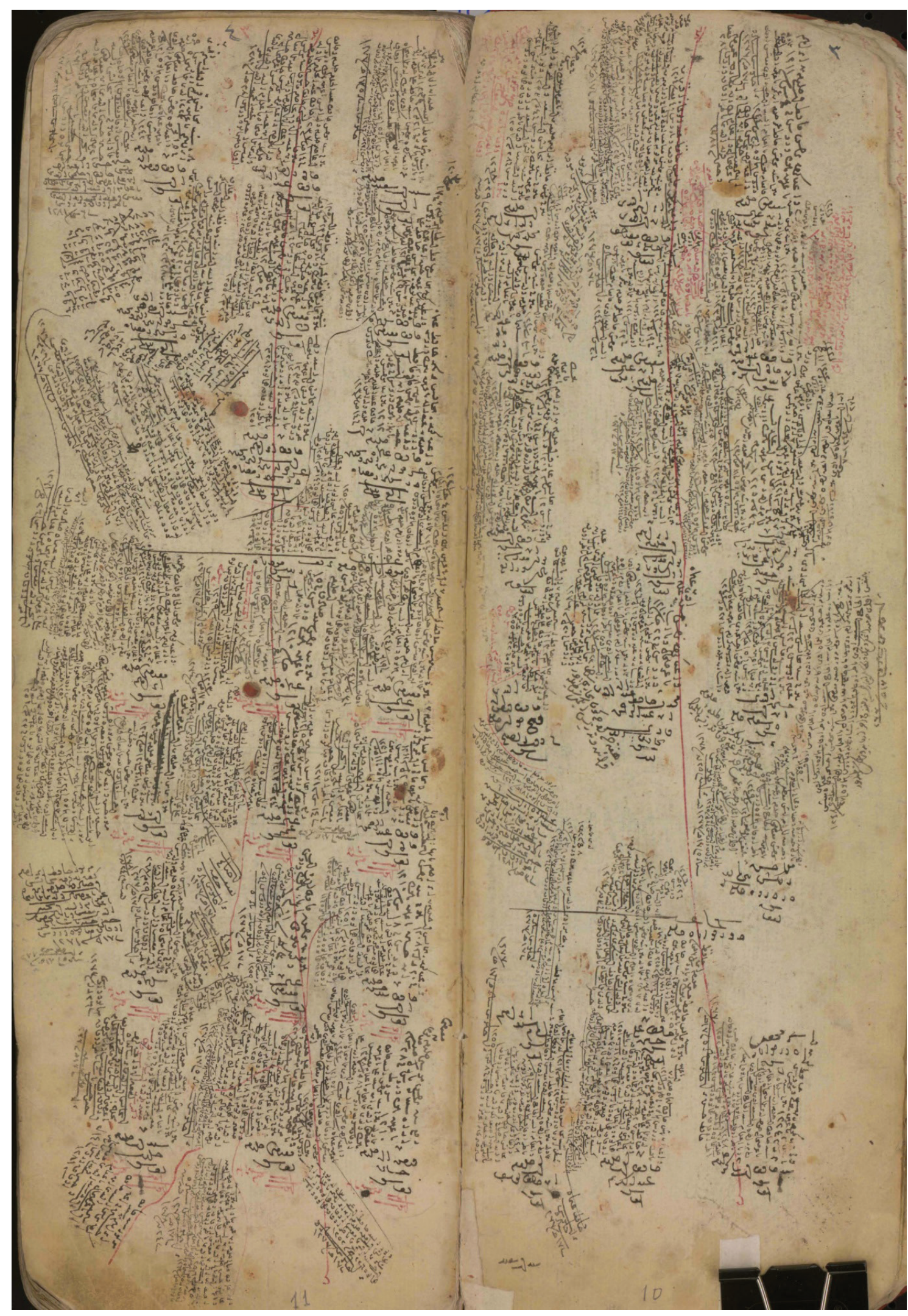

Vakıflar Dergisi 47 - Haziran 2017 
Ek 5: Hazine (Atik) Defterinin baş kısmında bulunan siyakat rakamları (VGMA, Defter No: 761)

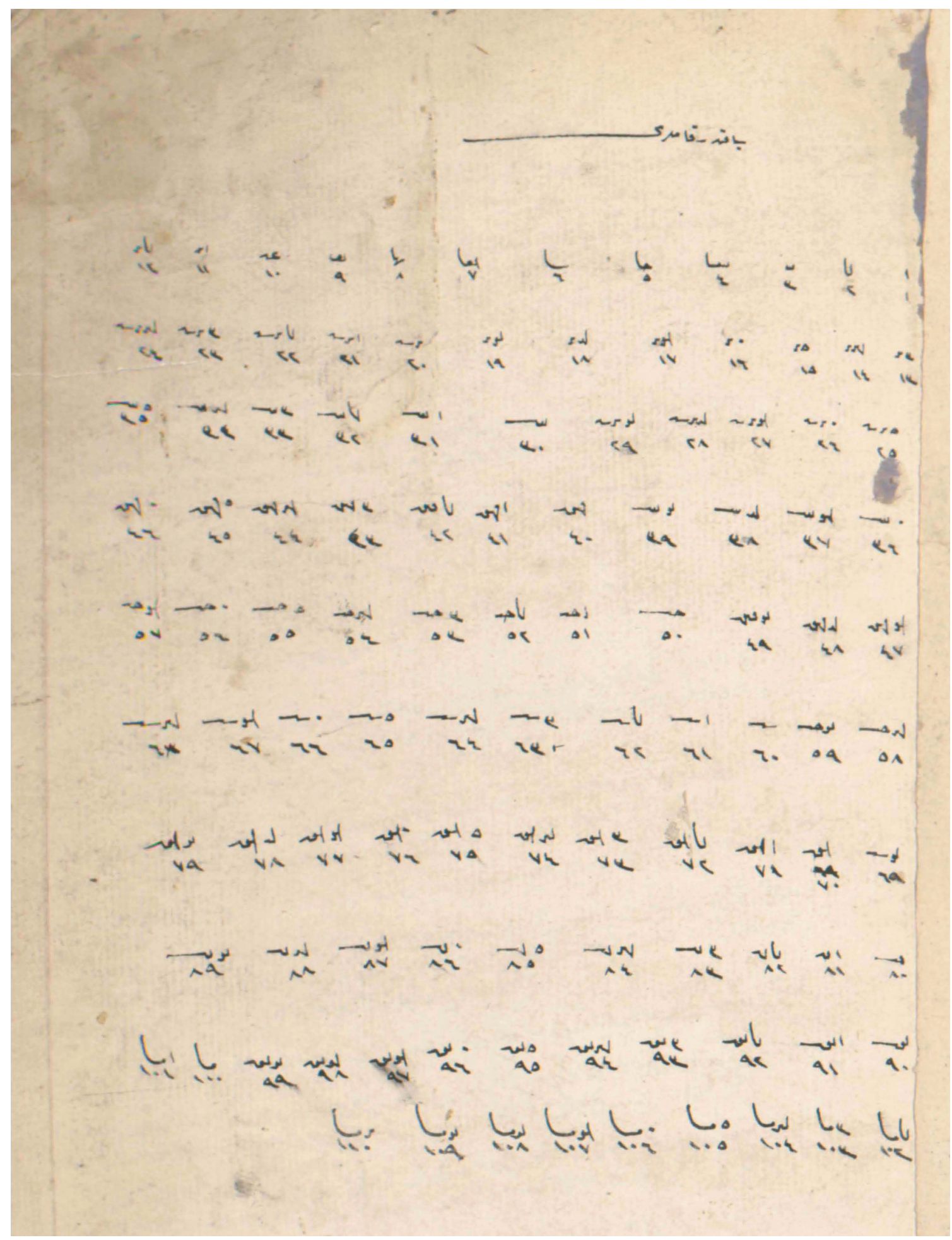


